\title{
Biomarkers in croakers Micropogonias furnieri (Teleostei: Sciaenidae) from polluted and non-polluted areas from the Patos Lagoon estuary (Southern Brazil): Evidences of genotoxic and immunological effects
}

\author{
Lílian Lund Amado ${ }^{\text {a,d }}$, Carlos Eduardo da Rosa ${ }^{\text {b,d }}$, Alice Meirelles Leite ${ }^{\text {b }}$, \\ Loraine Moraes d, Wagner Vaz Pires c , Grasiela L. Leães Pinho a, \\ Camila Martinez Gaspar Martins b, Ricardo Berteaux Robaldo d',

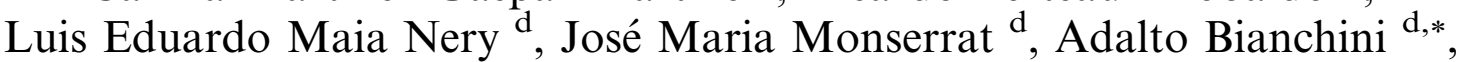 \\ Pablo Elias Martinez ${ }^{\mathrm{d}}$, Laura Alicia Geracitano ${ }^{\mathrm{d}}$ \\ ${ }^{a}$ Programa de Pós-Graduação em Oceanografia Biológica, Fundação Universidade Federal do Rio Grande, Av. Itália Km 8, \\ Campus Carreiros, 96201-900, Rio Grande, RS, Brazil \\ b Programa de Pós-Graduação em Ciências Fisiológicas-Fisiologia Animal Comparada, Fundação Universidade Federal do Rio Grande, \\ Av. Itália Km 8, Campus Carreiros, 96201-900, Rio Grande, RS, Brazil \\ c Curso de Graduação em Ciências Biológicas, Fundação Universidade Federal do Rio Grande, Av. Itália Km 8, Campus Carreiros, \\ 96201-900, Rio Grande, RS, Brazil \\ d Departamento de Ciências Fisiológicas, Fundação Universidade Federal do Rio Grande, Av. Itália Km 8, Campus Carreiros, \\ 96201-900, Rio Grande, RS, Brazil
}

\begin{abstract}
Biomarkers of exposure and effect of pollutants were analyzed in croakers Micropogonias furnieri (Teleostei: Sciaenidae) captured in winter and summer in a polluted and in a non-polluted site at the Patos Lagoon estuary (Southern Brazil). Catalase and glutathione $S$ transferase activities (exposure biomarkers) and lipid peroxidation (effect biomarker) were analyzed in liver samples. Other two effect biomarkers were also studied: blood cells DNA damage (through comet assay and micronucleus test) and respiratory burst measurements. In a broad view, results point to an important seasonal variation of the biochemical biomarkers analyzed. However, data obtained clearly indicate that croakers collected in winter at the polluted site were subjected to a level of clastogenic agents sufficient to generate irreversible genetic damages (mutations) and impair the fish immune system.
\end{abstract}

(c) 2005 Elsevier Ltd. All rights reserved.

Keywords: Aquatic pollution; Biomarkers; Croaker; DNA damage; Estuaries; Immune responses

\section{Introduction}

Estuaries are important sinks of pollutants derived from anthropogenic activities. Fish inhabiting these areas have been proposed as sentinels for pollution monitoring

\footnotetext{
${ }^{*}$ Corresponding author. Tel.: +55 533233 6853; fax: +55 5332336850 .

E-mail address: adalto@octopus.furg.br (A. Bianchini).
}

through assessment of sensitive biomarkers. Biomarkers can be defined as a change in biological response, ranging from molecular through behavioral changes, which can be related to exposure or effects of environmental contaminants (Depledge et al., 1995). Exposure biomarkers can be defined as any xenobiotic, its metabolite or the interaction product between the xenobiotic and a molecule or cell that is measured in organisms or in subunits of them 
(Depledge et al., 1995; López-Barea and Pueyo, 1998). Effect biomarkers represent any biochemical, physiological, behavioral (or other) alteration that can modify the well-being of an organism. Several molecular and cellular components in different fish species have been used as exposure and effect biomarkers, including biochemical, immunological and genetic parameters (van der Oost et al., 2003).

In the present study, the croaker Micropogonias furnieri (Teleostei: Sciaenidae) was used as sentinel of aquatic pollution, since this species is estuarine-dependent, being restricted to the Patos Lagoon estuary (Southern Brazil) during its juvenile phase (up to $16 \mathrm{~cm}$ total length) (Gonçalves et al., 1999). Fish larger than $16 \mathrm{~cm}$ perform a reproductive migration out of the estuary. After this, they occasionally use the estuary for feeding. The Patos Lagoon estuary is characterized by semi-enclosed bays of shallow waters. Some of these bays have been reported to be highly polluted, such as the "Mangueira Inlet" (Almeida et al., 1993). Baumgarten and Niencheski (1998) reported that sediment collected in this region is enriched with copper, lead and zinc. Also, previous studies from Geracitano et al. (2004a,b) showed that the estuarine polychaeta Laeonereis acuta from the "Mangueira Inlet" had higher antioxidant enzyme activity than that collected at a reference site, the "Justino Inlet". Other non-polluted areas are also found in the Patos Lagoon estuary. An example is the "Arraial Inlet", which is part of the Atlantic Forest Biosphere Reserve (Marcuzzo et al., 1998), and is considered a reference site.

The aim of the present study was to investigate if aquatic pollutants present in the "Mangueira Inlet" are generating biological responses by comparing croakers from this site with those collected in the "Arrail Inlet", a non-polluted site. To accomplish this objective, exposure and effect biomarker responses were measured in tissue samples from croakers collected in these two regions, in winter and summer. This study is part of a large-scale project conducted in several estuaries along the Brazilian coast in order to evaluate and detect pollution concerns in coastal and estuarine areas (www.mileniodomar.org.br).

\section{Material and methods}

Fish sampling was performed in August 2003 (winter) and February 2004 (summer) in two sites of the Patos Lagoon estuary (Southern Brazil). The first one is located close to the "Marinheiros Island" in a region called "Arraial Inlet" $\left(32^{\circ} 02^{\prime} \mathrm{S}-52^{\circ} 12^{\prime} \mathrm{W}\right)$, which was considered the non-polluted site (reference site). The second site is located at the "Mangueira Inlet" $\left(32^{\circ} 05^{\prime} \mathrm{S}-52^{\circ} 07^{\prime} \mathrm{W}\right)$, which was previously characterized as a polluted site (Fig. 1). Fish collection was performed for $15 \mathrm{~min}$ using a trawl-net. Fish between 10 and $20 \mathrm{~cm}$ were anaesthetized with benzocaine $(50 \mathrm{ppt})$ and weighed. Blood samples were taken from the caudal artery with heparinized syringes with needles $27 / 7$. Samples were immediately used for comet assay and micro-

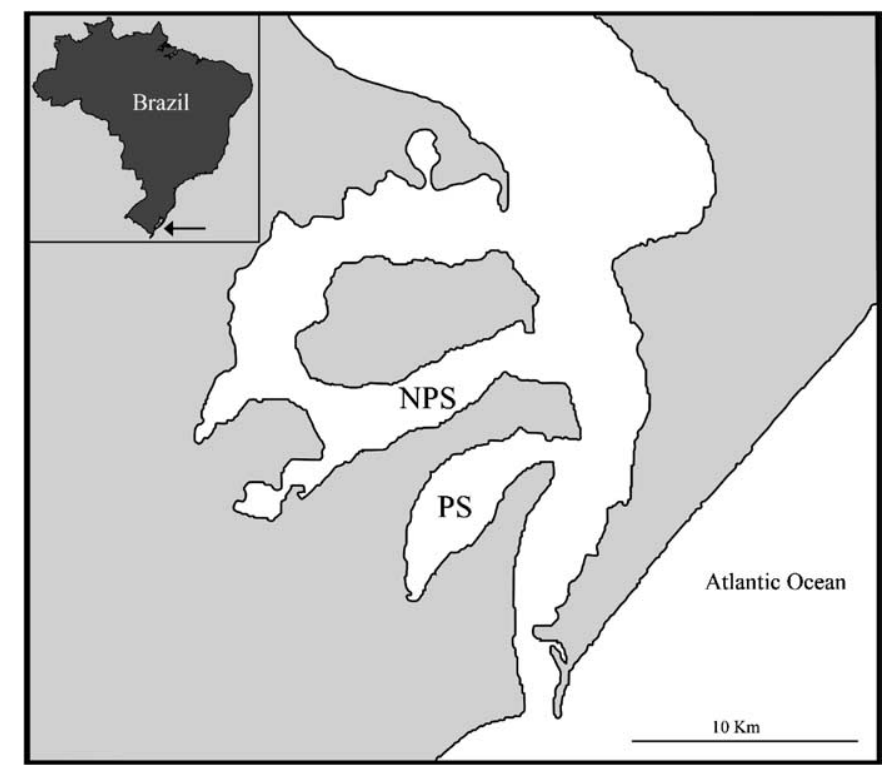

Fig. 1. Sites of Micropogonias furnieri (Teleostei: Scianidae) collection at the Patos Lagoon estuary (Southern Brazil). Non-polluted site (NPS) at "Arraial Inlet" $\left(32^{\circ} 02^{\prime} \mathrm{S}-52^{\circ} 12^{\prime} \mathrm{W}\right)$ and polluted site (PS) at "Mangueira Inlet" $\left(32^{\circ} 05^{\prime} \mathrm{S}-52^{\circ} 07^{\prime} \mathrm{W}\right)$.

nucleus test, as described below. Liver, spleen and anterior kidney were immediately dissected. Livers were frozen in liquid nitrogen and then stored at $-80{ }^{\circ} \mathrm{C}$ until enzyme assays and metallothionein-like proteins determination, as described below. Spleen and anterior kidney were collected, placed in $10 \mathrm{~mL}$ of Hank's balanced salt solution (HBSS: $200 \mathrm{mM} \mathrm{NaCl}, 1 \mathrm{mM} \mathrm{KCl}, 0.2 \mathrm{mM} \mathrm{Na} 2 \mathrm{HPO}_{4}, 0.08 \mathrm{mM}$ $\mathrm{KH}_{2} \mathrm{PO}_{4}, 1.2 \mathrm{mM}$ Glucose, $100 \mathrm{U} / \mathrm{mL}$ Sodium Heparin, $100 \mathrm{U} / \mathrm{mL}$ Penicillin and $100 \mu \mathrm{g} / \mathrm{mL}$ Streptomycin; $\mathrm{pH}$ 7.4) and maintained on ice until leukocyte respiratory burst measurements, as described below.

Water chemistry parameters (salinity, $\mathrm{pH}$, and temperature) were measured directly in the field.

\subsection{Exposure biomarkers}

To determine catalase (CAT) and glutathione- $S$-transferase (GST) activities, liver samples were processed according to previously established protocols with minor modifications (Livingstone, 1988). They were homogenized $(1: 5 \mathrm{w} / \mathrm{v})$ in cold $\left(4^{\circ} \mathrm{C}\right)$ buffer solution containing $20 \mathrm{mM}$ Tris-Base, $1 \mathrm{mM}$ EDTA, $1 \mathrm{mM}$ dithiothreitol (Sigma, St. Louis, MO), $500 \mathrm{mM}$ sucrose, $150 \mathrm{mM} \mathrm{KCl}, 0.1 \mathrm{mM}$ phenylmethylsulphonyl fluoride (PMFS, Sigma), with $\mathrm{pH}$ adjusted to 7.60. Homogenates were then centrifuged at $9000 \times g$, for $30 \mathrm{~min}$ at $4{ }^{\circ} \mathrm{C}$. The supernatant of each sample was collected and stored at $-20^{\circ} \mathrm{C}$, for no longer than a week, until analysis.

CAT activity was determined following the method described by Beutler (1975), which measure the rate of enzymatic decomposition of $\mathrm{H}_{2} \mathrm{O}_{2}$ (Merck, Darmstadt, Germany) as absorbance decrements at $240 \mathrm{~nm}$. Enzyme activity was expressed in CAT units, where one unit is 
the amount of enzyme needed to hydrolyze $1 \mu \mathrm{mol}$ of $\mathrm{H}_{2} \mathrm{O}_{2} / \mathrm{min} / \mathrm{mg}$ protein, at $30{ }^{\circ} \mathrm{C}$ and $\mathrm{pH} 8.00$.

GST activity was assessed following the method described by Habig and Jakoby (1981). This method is based on the conjugation of $1 \mathrm{mM}$ glutathione (Sigma) with $1 \mathrm{mM}$ of 1-chloro-2,4-dinitro-benzene (CDNB; Sigma). Enzyme activity was measured as absorbance increments at $340 \mathrm{~nm}$ and was expressed in GST units, where one unit is the amount of enzyme necessary to conjugate $1 \mu \mathrm{mol} \mathrm{de}$ $\mathrm{CDNB} / \mathrm{min} / \mathrm{mg}$ protein, at $25^{\circ} \mathrm{C}$ and $\mathrm{pH} 7.00$.

Total protein content in homogenates was measured using a commercial kit (Doles Reagentes Ltda., Goiânia, Brazil), which is based on the Biuret protein assay. Both enzymatic and protein content determinations were performed at least in duplicate.

Metallothionein-like proteins (MT) were determined employing the method described by Viarengo et al. (1997). Livers were homogenized in a cold buffer solution containing sucrose $(500 \mathrm{mM})$, Tris- $\mathrm{HCl}(20 \mathrm{mM})$, PMFS $(0.5 \mathrm{mM})$ and $\beta$-mercaptoethanol $(0.01 \%)$ as reducing agent. The $\mathrm{pH}$ was adjusted to 8.60. MT content was estimated spectrophotometrically $(412 \mathrm{~nm})$ using 5,50-dithiobis(2-nitrobenzoic acid) (DTNB $0.43 \mathrm{mM}$; from Sigma). Different glutathione (GSH) concentrations ranging from 0 to $500 \mu \mathrm{M}$ were employed as standards. MT concentration was expressed in terms of GSH equivalents $(\mu \mathrm{mol}$ $\mathrm{GSH} / \mathrm{g}$ of wet tissue).

\subsection{Effect biomarkers}

Lipid peroxidation (LPO) was determined in liver samples, according to Hermes-Lima et al. (1995). The method is based on the oxidation of $\mathrm{Fe}^{2+}$ by lipid hydroperoxides (FOX reactive substances) at acid $\mathrm{pH}$ in the presence of the $\mathrm{Fe}^{3+}$-complexing dye, xylenol orange (Sigma). Samples were homogenized $(1: 15 \mathrm{w} / \mathrm{v})$ in $100 \%$ cold $\left(4^{\circ} \mathrm{C}\right)$ methanol. The homogenate was then centrifuged at $1000 \times g$, for $10 \mathrm{~min}$ at $4{ }^{\circ} \mathrm{C}$. The supernatant was collected and used for LPO determination $(580 \mathrm{~nm})$. Cumene hydroperoxide (CHP; Sigma) was employed as standard.

DNA damage was assessed through two tests: comet assay that detect DNA double or single strand breaks which can be repaired; and micronucleus test that detect irreversible genetic damage. Comet assay was performed as described by Singh et al. (1988) and Tice et al. (2000) with some modifications. Fully frosted microscope slides were coated with $300 \mu \mathrm{L} 0.65 \%$ normal melting point agarose (NMPA; Gibco BRL) in TAE buffer $(40 \mathrm{mM}$ TrisAcetate, $1 \mathrm{mM}$ EDTA). Croaker blood samples were diluted $(5: 1000 \mathrm{v} / \mathrm{v})$ in phosphate buffer saline (PBS) and $20 \mu \mathrm{L}$ of cell suspension were mixed with $150 \mu \mathrm{l}$ of $0.65 \%$ low melting point agarose (LMPA; Gibco BRL) prepared with Kenny's salt solution $(400 \mathrm{mM} \mathrm{NaCl}, 9 \mathrm{mM} \mathrm{KCl}$, $0.7 \mathrm{mM} \mathrm{K}_{2} \mathrm{HPO}_{4}, 2 \mathrm{mM} \mathrm{NaHCO}$, pH 7.5) at $30{ }^{\circ} \mathrm{C}$ (Steinert, 1995). Slides were immersed in freshly made lysing solution $(10 \%$ DMSO, $1 \%$ Triton $\mathrm{X}-100,2.5 \mathrm{M} \mathrm{NaCl}$, $100 \mathrm{mM}$ EDTA, $10 \mathrm{mM}$ Tris, $1 \%$ sodium sarcosinate; $\mathrm{pH}$
10) overnight at $4{ }^{\circ} \mathrm{C}$. To allow DNA to unwind, slides were placed in an electrophoresis buffer $(10 \mathrm{~N} \mathrm{NaOH}$, $200 \mathrm{mM}$ EDTA; pH between 12 and 13) for $15 \mathrm{~min}$. Electrophoresis was carried out at $25 \mathrm{~V}$ and $300 \mathrm{~mA}$ for $20 \mathrm{~min}$. After electrophoresis, slides were washed three times with neutralizing solution $(0.4 \mathrm{M}$ Tris, $\mathrm{pH} 7.5)$ and stained with $70 \mu \mathrm{L}$ of ethidium bromide $(20 \mu \mathrm{g} / \mathrm{mL})$. The presence of comets was examined using a Zeiss axioplan fluorescent microscope (400X). DNA migration was visually determined in 100 cells per croaker. Comets were classified into five different groups: 0 for intact cells; 1,2 and 3 for intermediary levels of breaks; and 4 for maximum damage. Results were expressed as scores, where 0 represents absence of damage and 400 indicates the highest damage registered in the 100 cells analyzed.

Micronucleus test was performed as described by Hooftman and de Raat (1982). A drop of croaker blood was smeared on microscope slides and air-dried. After fixation with methanol for $10 \mathrm{~min}$, slides were stained with $5 \%$ Giemsa (Merck) in phosphate buffer $\left(60 \mathrm{mM} \mathrm{KH} \mathrm{KH}_{4}\right.$ and $60 \mathrm{mM} \mathrm{Na}{ }_{2} \mathrm{HPO}$; $\mathrm{pH}$ 6.8) for $20 \mathrm{~min}$, washed with distilled water and air-dried. The relative frequency of micronucleated cells was evaluated under light microscope (1000x magnification) by scoring an average of 2000 mononucleated erythrocytes per slide.

For respiratory burst measurements, head-kidney and spleen leukocytes were isolated following procedures described by Chung and Secombes (1988). Head-kidneys and spleens were pushed through a $100 \mu \mathrm{m}$ nylon mesh with HBSS. The cell suspension obtained was centrifuged at $400 \times \mathrm{g}$, for $10 \mathrm{~min}$. The pellet was resuspended in $2 \mathrm{~mL}$ of HBSS and centrifuged again at $600 \times g$ for $30 \mathrm{~min}$ in a $34-51 \%$ Percoll $^{\circledR}$ gradient. Isolated leucocytes were then collected, resuspended in $5 \mathrm{~mL}$ of HBSS and centrifuged at $400 \times g$ for $10 \mathrm{~min}$. The pellet was resuspended in $2 \mathrm{~mL}$ of Roswell Park Memorial Institute-1640 (RPMI1640, Gibco), supplemented with penicillin $(140 \mathrm{IU} / \mathrm{mL})$, streptomycin $(58 \mu \mathrm{g} / \mathrm{mL})$, gentamicin $(10 \mu \mathrm{g} / \mathrm{mL})$, sodium bicarbonate $(0.75 \mathrm{mg} / \mathrm{mL})$, HEPES solution $1 \mathrm{M}(0.02 \mathrm{~mL} /$ $\mathrm{mL})$, heparin sodium $(50 \mathrm{IU} / \mathrm{mL})$ and heat-inactivated $\left(37^{\circ} \mathrm{C}\right.$ for $\left.30 \mathrm{~min}\right)$ fetal bovine serum $(0.01 \mathrm{~mL} / \mathrm{mL})$. Leucocytes were counted in a Neubauer hemocytometer and the cell suspension was adjusted to $10 \times 10^{6}$ cells $/ \mathrm{mL}$. Cell viability was greater than $95 \%$, as determined by the Trypan blue exclusion test. The phagocyte oxidative burst assay (nitroblue tetrazolium reduction) was performed according procedures described by Rice et al. (1996). In a microplate, $100 \mu \mathrm{L}$ of cell suspension, $30 \mu \mathrm{L}$ of fetal bovine serum, $140 \mu \mathrm{L}$ of a nitroblue tetrazolium (NBT) solution $(179 \mu \mathrm{g} / \mathrm{mL})$ made with phosphate buffered saline solution (PBS) and $30 \mu \mathrm{L}$ of phorbol myristate acetate $\left(10^{-5} \mathrm{M}\right)$ were added for the stimulated assay. For the non-stimulated assay, phorbol myristate acetate was replaced by PBS. Each sample was analyzed in triplicate. The microplate was then incubated for $30 \mathrm{~min}$ at $25^{\circ} \mathrm{C}$ in a wet chamber with occasional shaking and centrifuged at $200 \times g$ for $10 \mathrm{~min}$. Pellets obtained were resuspended in $250 \mu \mathrm{L}$ of 
PBS after centrifugation at $200 \times g$ for $10 \mathrm{~min}$, and fixed with $100 \mu \mathrm{L}$ of $100 \%$ methanol for $1 \mathrm{~min}$. In each well, $150 \mu \mathrm{L}$ of $70 \%$ methanol were added and the microplate was centrifuged at $400 \times g$ for $5 \mathrm{~min}$. Supernatants were removed and the microplate was air-dried overnight at $25^{\circ} \mathrm{C}$. Pellets were resuspended in $20 \mu \mathrm{L}$ of a $0.1 \%$ Triton X 100 solution. After $30 \mathrm{~min}$, they were solubilized in $140 \mathrm{~mL}$ of a $2 \mathrm{M} \mathrm{KOH}$ solution, and $120 \mathrm{~mL}$ of dimethylsulfoxide (DMSO) were added and mixed by pipetting. The optical density was then measured in a spectrophotometer at $630 \mathrm{~nm}$.

\subsection{Statistical analysis}

Data were analyzed through two-way ANCOVA (factors: season and sampling site; covariate: weight) followed by post-hoc mean comparisons test (Tukey's test). Analysis assumptions (normality and variance homogeneity) were previously checked (Zar, 1984). Significance level adopted was $95 \%$. Results were expressed as mean \pm standard error.

\section{Results}

Water chemistry (temperature, $\mathrm{pH}$, salinity and dissolved oxygen) measured at the moment of fish collection is shown in Table 1. Values for all parameters measured were similar in the two sites for both seasons and had no relationship with any biomarker data.

Morphometric (length and weight) parameters of collected fish are listed in Table 2. At the non-polluted site, winter croakers were bigger $(P<0.05)$ than summer ones.

\section{Table 1}

Environmental parameters registered in winter 2003 and summer 2004 at the polluted and non-polluted sites of the Patos Lagoon estuary (Southern Brazil)

\begin{tabular}{llcrrr}
\hline Site & Season & Temperature $\left({ }^{\circ} \mathrm{C}\right)$ & Salinity & DO $(\mathrm{mg} / \mathrm{L})$ & $n$ \\
\hline Non-polluted & Winter & $13 \pm 0$ & $0.2 \pm 0.1$ & $9.2 \pm 0.2$ & 4 \\
Non-polluted & Summer & $24.3 \pm 0.3$ & $11.4 \pm 3.8$ & $8.5 \pm 0.1$ & 4 \\
Polluted & Winter & $9.5 \pm 0.3$ & $1.8 \pm 0.2$ & $10.1 \pm 0.3$ & 4 \\
Polluted & Summer & $24.3 \pm 0.5$ & $6.2 \pm 1.7$ & $7.6 \pm 0.4$ & 4 \\
\hline
\end{tabular}

DO: dissolved oxygen; $n$ : number of measurements. Values are expressed as means \pm 1 standard error.

Table 2

Morphometric data of croakers (Micropogonias furnieri) collected in winter 2003 and summer 2004 in the polluted and non-polluted sites of the Patos Lagoon estuary (Southern Brazil)

\begin{tabular}{lllll}
\hline Site & Season & Length $(\mathrm{cm})$ & Weight $(\mathrm{g})$ & $n$ \\
\hline Non-polluted & Winter & $15.9 \pm 0.7 \mathrm{a}$ & $42.0 \pm 7.4 \mathrm{a}$ & 10 \\
Non-polluted & Summer & $13.7 \pm 0.2 \mathrm{~b}$ & $22.1 \pm 1.3 \mathrm{~b}$ & 10 \\
Polluted & Winter & $13.3 \pm 0.5 \mathrm{~b}$ & $22.5 \pm 3.0 \mathrm{~b}$ & 10 \\
Polluted & Summer & $13.9 \pm 0.5 \mathrm{~b}$ & $24.3 \pm 1.9 \mathrm{~b}$ & 10 \\
\hline
\end{tabular}

Different letters indicate significant differences $(P<0.05)$ between mean values for fish collected in the different sites and seasons. $n$ : number of croakers collected.
They were also bigger than that from the polluted site in both seasons. However, in all cases weight (covariate) did not influence the statistical analysis, being verified a parallelism in the relationship between weight and both factors (season and sampling site).

\subsection{Exposure biomarkers}

\subsubsection{Enzyme (CAT and GST) activities and metallothionein-like proteins (MT) concentration}

Summer croakers from the non-polluted site showed significantly $(P<0.05)$ higher CAT $(90.8 \pm 13.2 \mathrm{U}$ CAT $)$ and GST $(0.65 \pm 0.09$ U GST $)$ activities than those collected in winter at the same site $(\mathrm{CAT}=40.0 \pm 4.5 \mathrm{U}$ CAT; $\mathrm{GST}=0.38 \pm 0.04 \mathrm{U}$ GST). Summer croakers from the polluted site also showed significantly $(P<0.05)$ higher CAT $(130.0 \pm 12.0 \mathrm{U}$ CAT $)$ and GST $(0.45 \pm 0.06 \mathrm{U}$ GST) activities than those collected in winter at the same site $(\mathrm{CAT}=40.5 \pm 4.0 \mathrm{U}$ CAT; $\mathrm{GST}=0.31 \pm 0.02 \mathrm{U}$ GST). In each season, no significant differences $(P>0.05)$ in CAT (Fig. 2a) and GST (Fig. 2b) activities were found
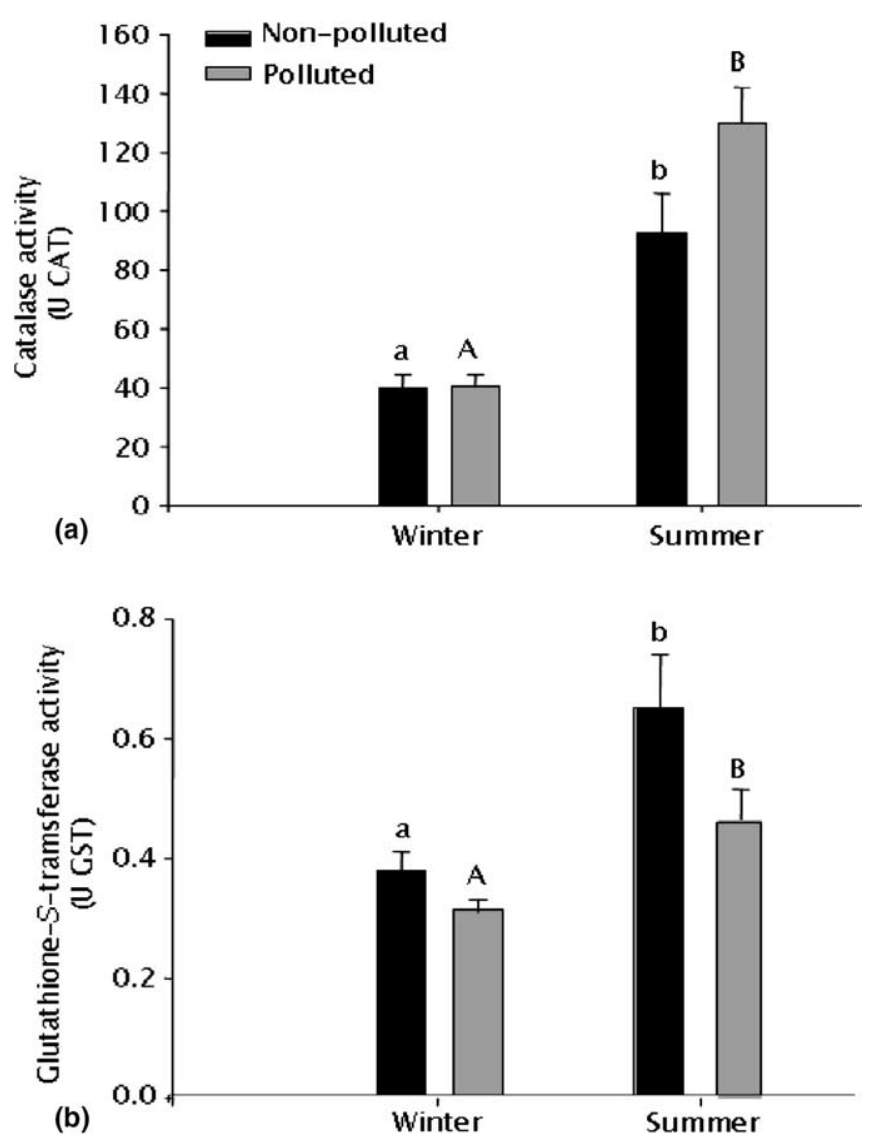

Fig. 2. Catalase (a) and glutathione- $S$-transferase (b) activity in croakers (Micropogonias furnieri) collected at the non-polluted and polluted sites in winter and summer. Different letters indicate seasonal significant differences $(P<0.05)$ for croakers from the non-polluted (lower case letters) and polluted (capital letters) sites. Significant differences $(P<0.05)$ between croakers from the non-polluted and the polluted site in the same season are indicated by an asterisk. Data are expressed as mean +1 standard error. 
between croakers from the polluted and non-polluted site. Also, no seasonal variations and significant differences $(P>0.05)$ were observed in the MT concentration of croakers from the non-polluted site (winter $=2.90 \pm 0.47$ and summer $=2.02 \pm 0.60 \mu \mathrm{mol} \mathrm{GSH} / \mathrm{g}$ of wet tissue) and the polluted site (winter $=3.13 \pm 0.47$ and $2.53 \pm 0.37 \mu \mathrm{mol}$ $\mathrm{GSH} / \mathrm{g}$ of wet tissue).

\subsection{Effect biomarkers}

\subsubsection{Lipid peroxidation ( $L P O)$ content}

Summer croakers from the non-polluted site showed significantly $(P<0.05)$ higher LPO content $(3325.8 \pm$ $438.0 \mathrm{nmol} \mathrm{CHP} / \mathrm{g}$ tissue) than those collected in winter at the same site $(981.6 \pm 188.2 \mathrm{nmol} \mathrm{CHP} / \mathrm{g}$ tissue). Croakers from the polluted site showed no significant $(P>0.05)$ difference in LPO content in summer $(1250.5 \pm$ $486.4 \mathrm{nmol} \mathrm{CHP} / \mathrm{g}$ tissue $)$ and winter $(1124.0 \pm 157.9 \mathrm{nmol}$ $\mathrm{CHP} / \mathrm{g}$ tissue). Significant difference between the two sites was only found in summer, when croakers from the nonpolluted site showed higher $(P<0.05)$ LPO content than those from the polluted site (Fig. 3a).

\subsubsection{Respiratory burst measurements}

Nitroblue tetrazolium reduction was higher in croakers from the non-polluted site than in those from the polluted site. In both seasons, optical density was higher $(P<0.05)$ in croakers from the non-polluted site (winter $=0.22 \pm$ 0.07 ; summer $=0.20 \pm 0.04$ ) than in those from the polluted site (winter $=0.09 \pm 0.04$; summer $=0.05 \pm 0.02$ ). No significant $(P>0.05)$ seasonal difference was observed in each sample site (Fig. 3b).

\subsubsection{DNA damage}

In winter, both biomarkers (comet assay, CA, Fig. 3c; and micronucleus test, MN, Fig. 3d) showed higher $(P<0.05)$ levels of DNA damage in croakers from the polluted site $(\mathrm{CA}=101.67 \pm 7.17 ; \mathrm{MN}=0.87 \pm 0.21)$ than in those from the non-polluted site $(\mathrm{CA}=38.00 \pm 5.83$; $\mathrm{MN}=0.18 \pm 0.04)$. In summer, there was no significant difference $(P>0.05)$ between croakers from the polluted site $(\mathrm{CA}=99.4 \pm 17.65 ; \mathrm{MN}=0.32 \pm 0.05)$ and the nonpolluted site $(\mathrm{CA}=57.71 \pm 11.85 ; \quad \mathrm{MN}=0.26 \pm 0.06)$, although CA results showed a tendency of higher values $(P=0.052)$ in croakers from the polluted site.

\section{Discussion}

Several field studies with different fish species have used the response of antioxidant and biotransformation enzymes as exposure biomarkers (van der Oost et al., 2003). In the present study, exposure biomarkers (CAT and GST) showed similar patterns in croakers from both polluted and non-polluted sites, but a clear seasonal
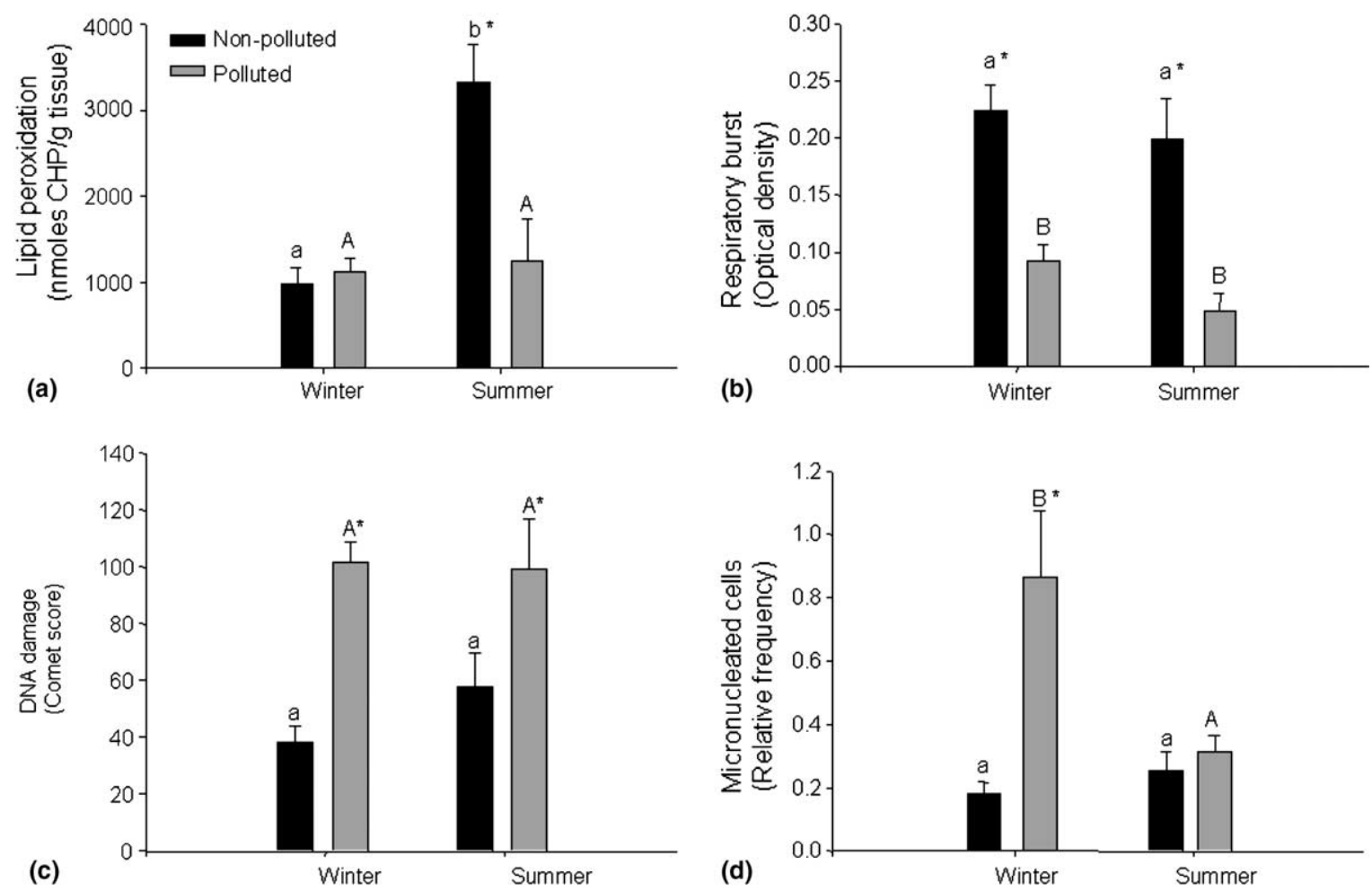

Fig. 3. Lipid peroxidation (a), respiratory burst (b), comet scores (c) relative frequency of micronucleated cells, (d) in croakers (Micropogonias furnieri) collected in the non-polluted and polluted sites in winter and summer. Different letters indicate seasonal significant differences $(P<0.05)$ for croakers from the non-polluted (lower case letters) and polluted (capital letters) sites. Significant differences $(P<0.05)$ between croakers from the non-polluted and the polluted site in the same season are indicated by an asterisk. Data are expressed as mean +1 standard error. 
variation was observed. Values were higher in the warmer season. Water chemistry parameters also showed an important seasonal variation, being similar in both studied sites (non-polluted and polluted). In a study with the fish Geophagus brasiliensis collected at a non-polluted site during spring and autumn, GST activity was also higher in the warmer period and CAT activity showed the same trend (Wilhelm Filho et al., 2001). Similar seasonal patterns of higher antioxidant and biotransformation enzymes activities in warmer seasons were also verified in other fish species (Ronisz et al., 1999). This response is probably related to the higher ambient temperature which can lead to an increase in oxygen consumption and therefore to an enhanced reactive oxygen species (ROS) generation. Seasonal adjustments in the antioxidant defense of thermoconformers, like most of fish and invertebrates, suggest that this mechanism is a common adaptation in these species (Wilhelm Filho et al., 2001).

The effect biomarkers (LPO content, DNA damage and respiratory burst measurement) showed different response patterns. LPO content in croakers from the non-polluted site showed a seasonal variation, being higher in summer. Polyunsaturated fatty acids (PUFA) from membrane phospholipids are the main target of ROS attack, leading to lipid peroxidation (Halliwell and Gutteridge, 1999). It is also known that membranes of cold-acclimated thermoconformers are enriched with PUFA, being more susceptible to suffer with oxidative stress (Parihar et al., 1996). On the other hand, croakers from the polluted site did not show any seasonal variation and had lower LPO values in summer than those from the non-polluted site, a priori, a non expected result. However, some authors have described the disruption of lipid metabolism due to PCBs exposure (Ferreira and Vale, 1998). Boutet et al. (2004) found an inhibition in the expression of the gene coding the enzyme $\Delta 9$ desaturase in oysters (Crassostrea gigas) exposed to hydrocarbons from 7 to 21 days. Desaturases are enzymes that catalyze the addition of double bonds in a fatty acyl chain, playing a critical role in PUFAs biosynthesis (Pereira et al., 2003). If pollutants are able to inactivate these enzymes, a possible interpretation to our results is that lipid peroxidation process could be reduced in croakers from the polluted site due to a lower content of PUFAs in the cell membranes of these fish. Thus, further studies analyzing the cell membrane fatty acid composition are needed to verify the lipid peroxidation potential of a specific tissue.

In the present study, DNA damage was assessed through two tests: the comet assay (CA), which detects DNA strand breaks that can be repaired, and the micronucleus test $(\mathrm{MN})$, which assess mutational events. It is known that breaks detected by comet assay can be transiently present when cells repair lesions via base or nucleotide excision. Thus, a high level of breaks in the comet assay may indicate either high damage or an efficient repair process (Collins et al., 1997). Our results suggest that DNA damage found through comet assay in croakers collected in winter at the polluted site was not efficiently repaired. This statement is based on the fact that micronucleus test indicated higher levels of mutations in these fish. Some of these mutations can be related to non-repaired breaks. In contrast, the tendency of higher DNA damage values in summer croakers did not lead to a higher micronucleus frequency, probably because breaks detected by comet assay in this season were of repairing nature. It seems that winter croakers were exposed to some contaminant or to a mixture of them that inhibited or exhausted their DNA repair mechanisms, leading to permanent damage, as showed by the micronuclei data. It should be stressed that the DNA damage determined through $\mathrm{CA}$ and $\mathrm{MN}$ was paralleled by a lack of CAT and GST induction in fish collected at the polluted site in winter. Catalase activity is essential to promote the degradation of $\mathrm{H}_{2} \mathrm{O}_{2}$, a precursor of hydroxyl radical, a reactive oxygen species that induces DNA damage (Halliwell and Gutteridge, 1999). In this context, the lack of CAT response in fish collected in winter at the polluted site should be unable to reduce the levels of hydroxyl radical promoters. The negative correlation between antioxidant defense competence and DNA damage was previously verified in other aquatic organisms such as Mytilus galloprovincialis, where individuals with lower total antioxidant capacity also showed lower DNA integrity (Frenzilli et al., 2001). Several in situ studies have been demonstrated the occurrence of higher DNA damage in organisms collected from polluted areas, both using the comet assay (Flammarion et al., 2002; Winter et al., 2004) and the micronucleus test (Minissi et al., 1996; Bombail et al., 2001), pointing to their utility in biomonitoring programs. However, few of the cited previous studies have analyzed the response in terms of DNA damage in different seasons, an important point to be considered among the several factors that can lead to augmented damage, as registered in the present study. Further research should consider the kinetics of DNA repair to analyze the effects of pollutants on this parameter.

Results from respiratory burst assay in croakers collected at the two sites of the Patos Lagoon estuary indicate that NBT reduction was higher in croakers from the nonpolluted site than in those from the polluted site. Since previous studies reported suppression of phagocytic function by environmental contaminants (Lutz and Wasowicz, 2003), our results suggest that croakers phagocytes are being exposed to sublethal concentrations of environmental contaminants in the Patos Lagoon estuary, leading to manifestations of immunosuppression. These lower non-specific immune responses can lead to opportunistic diseases, such as viral infections and infestation with parasites, as previously determined in the fish Ammodytes hexapterus after hydrocarbon exposure (Moles and Wade, 2001).

Based on results presented here, it is not possible to point out a single chemical in the Patos Lagoon estuary that is causing the alterations observed in the present study. However, they suggest that synergistic effects from a com- 
bination of chemicals can be affecting immune response and also causing DNA damage in croakers collected at the polluted site. The metabolism of several pollutants generates ROS that can attack any cellular components as DNA, fatty acids, carbohydrates and proteins, leading to serious damages to cellular macromolecules (Livingstone, 2001). Data showed here indicate that winter croakers from the polluted site were subjected to a level of pollutants enough to impair fish immunological activity and also to overwhelm the DNA repair mechanisms, generating irreversible genetic damages (mutations). Previous studies of Geracitano et al. $(2004 a, b)$ reported augmented antioxidant responses in the estuarine polychaeta Laeonereis acuta collected at polluted regions from the Patos Lagoon estuary, suggesting the existence of pollutants that can generate ROS. However, contrary to results reported by Geracitano et al. (2004a), no significant differences in liver MT levels were found in croakers from the non-polluted and polluted sites. Thus, higher rates of ROS production could be deleterious for croakers since no responses of any important antioxidant defense, such as catalase or GST activity, which helps to eliminate the oxidative by-products (Leaver and George, 1998), was observed in croakers collected in the polluted site. Furthermore, the fact that the polluted site is characterized by higher levels of metals like copper and arsenium (Seeliger and Costa, 1998; Mirlean et al., 2003) and hydrocarbons (Medeiros et al., 2005) that can generate ROS, gives support to our hypothesis.

\section{Acknowledgements}

This work was supported by the Brazilian Ministry of Science and Technology (PROJETO RECOS-INSTITUTO DO MILÊNIO-www.milieniodomar.org.br). A. Bianchini and J.M. Monserrat are research fellows from Brazilian CNPq.

\section{References}

Almeida, M.T.A., Baumgarten, M.G.Z., Rodrigues, R.M.S., 1993. Identificação das possíveis fontes de contaminação das águas que margeiam a cidade do Rio Grande. Documentos Técnicos 6, 7-30.

Baumgarten, M.G.Z., Niencheski, L.F.H., 1998. Avaliação da qualidade hidroquímica da área portuária da cidade do Rio Grande (RS). Documentos Técnicos-Oceanografia 9, 1-66.

Beutler, E., 1975. The preparation of red cells for assay. In: Beutler, E. (Ed.), Red Cell Metabolism: A Manual of Biochemical Methods. Grune \& Straton, New York, pp. 8-18.

Bombail, V., Aw, D., Gordon, E., Batty, J., 2001. Application of the comet and micronucleus assays to butterfish (Pholis gunnelus) erythrocytes from the firth of forth, Scotland. Chemosphere 44, 383-392.

Boutet, I., Tanguy, A., Moraga, D., 2004. Response of the Pacific oyster Crassostrea gigas to hydrocarbon contamination under experimental conditions. Gene 329, 147-157.

Chung, S., Secombes, J., 1988. Analysis of events occurring within teleost macrophages during the respiratory burst. Comparative Biochemistry and Physiology 539C, 539-544.

Collins, A.R., Dobson, V.L., Dusinská, M., Kennedy, G., Stetina, R., 1997. The comet assay: what it can really tell us. Mutation Research $375,183-193$.
Depledge, M.H., Aagaard, A., Györkös, R., 1995. Assessment of trace metal toxicity using molecular, physiological and behavioural biomarkers. Marine Pollution Bulletin 31, 19-27.

Ferreira, A.M., Vale, C., 1998. PCB accumulation and alterations of lipids in two length classes of the oyster Crassostrea angulata and of the clam Ruditapes decussatus. Marine Environmental Research 45, 259 268.

Flammarion, P., Devaux, A., Nehls, S., Migeon, B., Noury, P., Garric, J., 2002. Multibiomarker responses in fish from the Moselle River (France). Ecotoxicology and Environmental Safety 51, 145-153.

Frenzilli, G., Nigro, M., Scarcelli, V., Gorbi, S., Regoli, F., 2001. DNA integrity and total oxyradical scavenging capacity in the Mediterranean mussel, Mytilus galloprovincialis: a field study in a highly eutrophicated coastal lagoon. Aquatic Toxicology 53, 19-32.

Geracitano, L.A., Monserrat, J.M., Bianchini, A., 2004a. Oxidative stress in Laeonereis acuta (Polychaeta: Nereididae): environmental and seasonal effects. Marine Environmental Research 58, 625-630.

Geracitano, L., Bocchetti, R., Monserrat, J., Regoli, F., Bianchini, A., 2004b. Oxidative stress responses in two populations of Laeonereis acuta (Polychaeta, Nereididae) after acute and chronic exposure to copper. Marine Environmental Research 58, 1-17.

Gonçalves, A.A., de Souza, J.A.F., Vieira, J.P., 1999. Descrição trófica dos primeiros estágios de vida de $M$. furnieri (Sciaenidae) no Estuário da Lagoa dos Patos, RS, Brasil. Atlântica 21, pp. 93-103.

Habig, W.H., Jakoby, W.B., 1981. Assays for differentiation of glutathione $S$-transferases. Methods on Enzymology 77, 398-405.

Halliwell, B., Gutteridge, J.M.C., 1999. Free Radicals in Biology and Medicine. Oxford University Press, New York, USA.

Hermes-Lima, M., Willmore, W., Storey, K., 1995. Quantification of lipid peroxidation in tissue extracts based on $\mathrm{Fe}(\mathrm{III}) x y l e n o l$ orange complex formation. Free Radical in Biology and Medicine 19, 271-280.

Hooftman, R.N., de Raat, W.K., 1982. Induction of nuclear anomalies (micronuclei) in the peripheral blood erythrocytes of the eastern mudminnow Umbra pygmaea by ethyl methanesulphonate. Mutation Research 104, 147-152.

Leaver, M.J., George, S.G., 1998. A piscine glutathione S-transferase which efficiently conjugates the endproducts of lipid peroxidation. Marine Environmental Research 46, 1-5.

Livingstone, D.R., 1988. Responses of microssomal NADPH-cytochrome $\mathrm{C}$ reductase activity and cytochrome P450 in digestive glands of Mytilus edulis and Littorina littorea to environmental and experimental exposure to pollutants. Marine Ecology Progress Series 46, 37-43.

Livingstone, D.R., 2001. Contaminant-stimulated reactive oxygen species production and oxidative damage in aquatic organisms. Marine Pollution Bulletin 42, 656-666.

López-Barea, J., Pueyo, C., 1998. Mutagen content and metabolic activation of promutagens by molluscs as biomarkers of marine pollution. Mutation Research 399, 3-15.

Lutz, W., Wasowicz, W., 2003. Metal-induced modulation of redox cellsignaling in the immune system. Comments on Toxicology 9, 59-83.

Marcuzzo, S., Pagel, S.M., Chiapetii, M.I.S., 1998. A Reserva da Biosfera da Mata Atlântica no Rio Grande do Sul-Situação atual, ações e perspectivas. In: Costa, J.P.O, Lino, C.F., Albuquerque, J.L. (Eds.), Série Cadernos da Biosfera da Mata Atlântica. Conselho Nacional da Reserva da Biosfera Mata Atlântica, São Paulo, p. 60.

Medeiros, P.M., Bícego, M.C., Castelao, R.M., Del Rosso, C., Fillmann, G., Zamboni, A.J., 2005. Natural and anthropogenic hydrocarbon inputs to sediments of Patos Lagoon estuary, Brazil. Environmental International 31, 77-87.

Minissi, S., Cicciotti, E., Rizzoni, M., 1996. Micronucleus test in erythrocytes of Barbus plebejus (Teleostei, Pisces) from two natural environments: a bioassay for mutagens detection in freshwater. Mutation Research 367, 245-251.

Mirlean, N., Andrus, V., Baisch, P., 2003. Mercury pollution sources in sediments of Patos Lagoon estuary, Southern Brazil. Marine Pollution Bulletin 46, 331-334.

Moles, A., Wade, T.L., 2001. Parasitism and phagocytic function among sand lance Ammodytes hexapterus, Pallas exposed to crude oil-laden 
sediments. Bulletin of Environmental Contaminant Toxicology 66, 528-535.

Parihar, M.S., Dubey, A.K., Javeri, T., Prakash, P., 1996. Changes in lipid peroxidation, superoxide dismutase activity, ascorbic acid and phospholipid content in liver of freshwater catfish Heteropneustes fossilis exposed to elevated temperature. Journal of Thermal Biology 21, 323-330.

Pereira, S., Leonard, A., Mukerji, P., 2003. Recent advances in the study of fatty acid desaturases from animals and lower eukaryotes. Prostaglandins, Leukotrienes and Essential Fatty Acids 68, 97-106.

Rice, C.D., Kergosien, D.H.E., Adams, M., 1996. Innate immune function as a bioindicator of pollution stress in fish. Ecotoxicology and Environmental Safety 33, 186-192.

Ronisz, D., Larsson, D.G.J., Förlin, L., 1999. Seasonal variations in the activities of selected hepatic biotransformation and antioxidant enzymes in eelpout (Zoarces viviparus). Comparative Biochemistry and Physiology 124C, 271-279.

Seeliger, U., Costa, C., 1998. Impactos naturais e humanos. In: Seeliger, U., Oderbrecht, C., Castello, J. (Eds.), Os ecossistemas costeiro e marinho do extremo sul do Brasil. Ecoscientia, Rio Grande.

Singh, N., McCoy, M., Tice, R., Schneider, E., 1988. A simple technique for quantitation of low levels of DNA damage in individual cells. Experimental Cell Research 175, 184-191.
Steinert, S.A., 1995. Contribution of apoptosis to observed DNA damage in mussel cells. Marine Environmental Research 42, 253-259.

Tice, R., Agurell, E., Anderson, D., Burlinson, B., Hartmann, A., Kobayashi, H., Miyamae, Y., Rojas, E., Ryu, J., Sasaki, Y., 2000. Single cell gel/comet assay: guidelines for in vitro and in vivo genetic toxicology testing. Environmental Molecular Mutagenesis 35, 206 221.

van der Oost, R., Beyer, J., Vermeulen, N.P.E., 2003. Fish bioaccumulation and biomarkers in environmental risk. Environmental Toxicology and Pharmacology 13, 57-149.

Viarengo, A., Ponzano, E., Dondero, F., Fabbri, R., 1997. A simple spectrophotometric method for metallothionein evaluation in marine organisms: an application to mediterranean and antartic molluscs. Marine Environmental Research 44, 69-84.

Wilhelm Filho, D., Torres, M., Tribess, T., Pedrosa, R., Soares, C., 2001. Influence of season and pollution on the antioxidant defenses of the cichlid fish acara (Geophagus brasiliensis). Brazilian Journal of Medical and Biological Research 34, 719-726.

Winter, M., Day, N., Hayes, R., Taylor, E., Butler, P., Chipman, J., 2004. DNA strand breaks and adducts determined in feral and caged chub (Leuciscus cephalus) exposed to rivers exhibiting variable water quality around Birmingham, UK. Mutation Research 552, 163-175.

Zar, J.H., 1984. Biostatistical Analysis. Prentice Hall, New Jersey. 